\title{
The Mausoleum of Giuseppe Tonietti on Elba Island. From a masterpiece of Adolfo Coppedè to a compromising state of decay
}

\author{
ANGELA MANCUSO, ANDREA PASQUALI, GIORGIO VERDIANI \\ University of Florence, Italy
}

\begin{abstract}
This study shows the results of the digital and photographic surveys carried out on an architectural work of great importance: the Mausoleum of the Tonietti family, designed by Adolfo Coppedè, built on the island of Elba in Tuscany at the beginning of the 20th century. The current alarming conditions of the building invite us to reflect on the unpleasant but common fate of many buildings of the Liberty and Eclectic periods in Italy. With the evolution of rationalism of the architectural form and thus the gradual elimination of decorative elements from architectural objects, architectural research, and with it the observation and conservation of cultural heritage, has increasingly focused on the new rational style, omitting many examples of floral style equally deserving of attention. The alarming state of preservation of the Tonietti Mausoleum, combined with the total absence of conservation projects by local authorities, set the conditions for the dissolution of the work and the consequent loss of the cultural and territorial connotation that it created. Processing of the survey data and the collection of documentation are intended to create the basis for the comparison of the work's original state and its current form, determining the current conditions of decay. One may hope that this work can lead to a practical impulse to conservation of this cultural property designed by the youngest of the Coppedè brothers, while giving it due recognition for its inherent qualities and position in the history of architecture.
\end{abstract}

Key words:

Digital survey, mausoleum, Liberty and eclectic architecture, Coppedè, Tuscany.

\section{SDH Reference:}

Angela Mancuso et al. 2017. The Mausoleum of Giuseppe Tonietti on Elba Island. From a masterpiece of Adolfo Coppedè to a compromising state of decay. SDH, 1, 2, 719-734.

D0I: $10.14434 /$ sdh.v1i2.23247

\section{HISTORICAL INTRODUCTION TO THE MONUMENT}

At the end of the nineteenth century, the island of Elba was the Italian center of iron mining. One of the most important mines was located in Rio Marina. The first concessionaire of this mine was Giuseppe Tonietti, a man of great capacities and moral integrity. Starting as a naval captain, Tonietti became a very rich man in Rio Marina and also an influential one, serving as a city counsellor and a "labor knight." In 1896 he died, leaving all his fortune to his wife and his son Ugo Ubaldo Tonietti. After

Author's address: Angela Mancuso, Andrea Pasquali, Giorgio Verdiani, Dept. of Architecture, University of Florence, Florence, Italy; email: mancusoangela@hotmail.com, pasqualiandrea@yahoo.it,giorgio.verdiani@unifi.it

Permission to make digital or hardcopies of part or all of this work is granted without fee according to the open access policy of SDH.

(C) 2017 SDH Open Access Journal 


\section{1:720 A. Mancuso et al.}

his temporary burial in a niche of the town cemetery [A.S.C.R.M.], his son decided to build a monumental chapel as a family tomb, in the place where his father used to walk and stare at the sea, on the peak of the Lentisco Mount. At that time, the Italian architect Adolfo Coppedè was working at Elba for the businessman Pilade del Buono, a long-standing friend of Tonietti's father. Ugo Tonietti commissioned Coppedè to design and the construct the chapel, which today is considered one of the best examples of the eclectic work of Adolfo Coppedè.

From the second half of the 20th century, with the extinction of the Tonietti family, the chapel was abandoned. Today it appears in an advanced and dangerous state of deterioration that will be object of discussion in this work.

\subsection{The Architect Adolfo Coppedè}

Adolfo Coppedè was born in Florence on April 29, 1871, the third son of Mariano Coppedè and Antonietta Bizzarri. He attended the Professional School of Decorative and Industrial Arts in Florence, and was a prize-winning student. In 1892 he enrolled at the Accademia di Belle Arti in Florence, but he only occasionally attended it, since he started working with his father and brothers as a wood sculptor. In 1898 and 1899, Adolfo Coppedè participated in the competitions for the Artistic Pensioner of Rome, winning the first contest and finishing second in the final one. On this occasion, he was noticed by the Hon. Pilade Del Buono, who led him to Elba, where Del Buono commissioned several works. In 1901 he married Anita Burchi, daughter of Augusto Burchi, a professor at the Academy of Fine Arts in Florence, and in 1902 he obtained the license for teaching Architectural Design.

During his career, he was in charge of many projects, including important palaces in Florence, for which he won the Premio Martelli three times (an award established by the Florentine architect Giuseppe Martelli, 1792-1876); several buildings in Milan; and the very important project for the salons of Borsa in Genoa. Between 1937 and 1950 he devoted himself to the administration of the Parugiano farm, in Montemurlo, near Florence. On August 15th, 1951, he died in Parugiano and is buried in the chapel of the villa.

\subsection{Coppedès' Style}

Important for our study is the position of Coppedè and his brother Gino in the Italian artistic and architectural milieu of the beginning of the last century. The Coppedè brothers are often framed as exponents of modernism and of the Italian Liberty style. However, their version of modernism stood in direct and open conflict with eclecticism and historicism, which extended to the coherent development of the idea of a building and its continuous formal architecture, which refused to proceed by successive additions, which promulgated the identification between function and decoration and which required forgetting the distinction between construction and architecture. A quick examination of the Coppedès' style shows that no characteristics of their works correspond to the features just mentioned. This is probably due to their different culture and the environment, as compared with other contemporary architects in Italy. This clear separation can be read in the total absence of the works of the Coppedès in all the textbooks about Liberty and Italian modernism. This is unfortunate: it would have been appropriate to mention the Coppedès' contributions and to give 
students a general picture of these eclectic architects who, in their own way, made a significant contribution to the architecture of the 1900s in Italy, especially in the cities of Genoa, Florence and Milan.

\subsection{Works on Elba and in Italy}

The Elba projects were quickly commissioned from Adolfo Coppedè. The first of these to be finished was the Del Buono Chapel in the cemetery of Portoferraio. In this work, there is still a strong element of the neo-Gothic style that distinguishes his early works and which would be the basis for his future developments. The other building that today is a symbol of Coppedè on Elba is the Palazzo dei Merli, unfortunately destroyed by bombing in 1943, but of which there are many photographs. This, too, was characterized by a neo-Gothic style. The true Coppedè style is first attested in the Tonietti Chapel. Other work done on Elba include the San Martino house and farm, the property of Pilade Del Buono, and the palazzo for the administrative offices of an iron mill.

At the end of his stay on Elba, Adolfo Coppedè returned to Italy, bringing back useful experiences in architectural design that resulted in further commissions, first in the Florence area and later in Genoa and Milan. Overall, his work as an architect was limited in comparison to the professional activity of his brother Gino, whom Adolfo had always seen as an inspiration and reference, always trying to outdo him [Bossaglia and Cozzi 1982].

In Florence in 1906 he built the Villa Pagani-Nefetti, for which he won for the first time the Hammer Award, and the Antonini house, with an elevation marked by two turrets and balconies supported by large talamoni; it was originally decorated with painted panels by Galileo Chini.

The peak of Adolfo Coppedè's architectural career was reached between 1909 and 1912 with the design of the interior of the halls of the New Exchange of Genoa. To the important achievements of this period are added several unrealized projects at an urban level, such as the project for the reordering of Piazza Colonna in Rome (1908), two reordering projects in Florence (1909-1910; 19101915) and the project for a monumental bridge over the Tiber river in Rome (1909-1912).

Another important creation that, after Genoa, marks the passage of Coppedeian style from Florence to the Northern Italy is the Palazzo Viviani-Cova (1910-1915) in Milan. Also in Milan are located the Palace in Via Elba (1912-1919) and the most important building in Via Broletto, setting of the National Fund for accidents at work (1913). The palace decorations are characterized by a mix of eclectic, baroque and secessionist references, with elements both floral and geometric.

In Florence Coppedè also designed the Villino Sequi-Bopp (1913-1914), the renovation of the Palazzo Pazzi-Quaratesi, headquarters of the Bank of Florence, for which he was the subject of numerous polemics, and the interior of the Agricultural Credit Bank in Piazza della Signoria, for which was appointed Grand Officer of the Crown of Italy. Between 1918 and 1919 he carried out the restoration of the Palazzo del Canto alle Rondini and the Ancient Pharmacy of Marco Palmieri. Between 1919 and 1925, he designed and built the House of Cellini, executed the renovation of the theatre-garden Alhambra in Piazza Beccaria (both of which no longer exist), the renovation of the Villa il Bargellino, he built the Castle Mezzaratta in Settignano and the Villa Bartolini Salimbeni, still existing even if with some changes. Dating to 1926 are the unrealized project for the "Mussolini Gallery" in Florence 


\section{1:722 A. Mancuso et al.}

and the façade of the parish church with accommodation of the square outside and the War Memorial and fountain in Radda in Chianti [Bossaglia and Cozzi 1982].

\section{THE TONIETTI MAUSOLEUM}

\subsection{Historical notes}

As mentioned above, at the end of 1800, Adolfo Coppedè went to Elba with Pilade del Buono. Through him he knew and met Giuseppe Tonietti, the first tenant of the mines of Rio Marina and one of the city councilors, who died at the age of sixty years, leaving his son an immense fortune to manage.

Ugo Ubaldo Tonietti decided to build a funerary chapel to honor his father. The area he chose was the top of the Mount Lentisco, the place where his father used to go for a walk and admire the sea (Figs. 1 and 2).
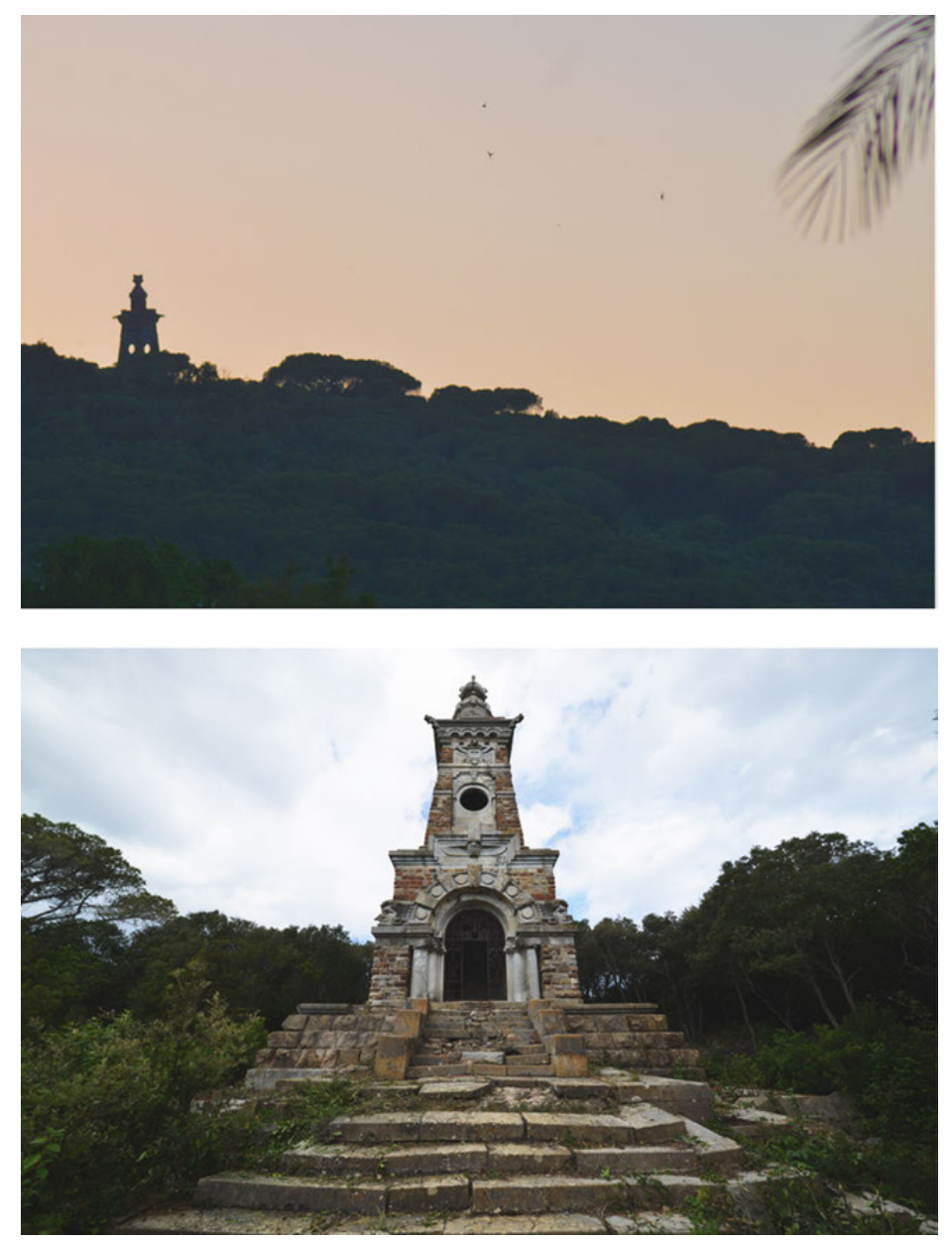

Figure 1 (above). Skyline with Tonietti's Mausoleum near the port of Cavo. Figure 2 (below). The façade of the Mausoleum. 
The Tonietti Chapel is considered the major work of Adolfo Coppedè, both on the island and among all his works. It is a witness to the climate of those years, the ambitions of the clients as well as the high quality of the designer [Bossaglia and Cozzi 1982]. The family chapel for the Tonietti is configured almost like a lighthouse that marks the route between Piombino and Portoferraio, rising majestically in the verdant forest. The association to the shape of the lighthouse, as well as its location, makes much more sense if there is a link to the beginning of Giuseppe Tonietti as owner and highly experienced navigator. According to some sources, the chapel is built of Elban granite, white marble and stone of the boulder of Fiesole. Moreover, the internal iron parts probably come from Officine Michelucci in Pistoia, Tuscany, and finally the painting that served as the altar backdrop, are probably the work of Carlo Coppedè, Adolfo's brother [Formenti and Magnani 1905]. For these features, it has been difficult to find confirmation now that most of the Coppedè files are difficult to access or have gone missing. The only exception is the front door: a picture is present in the book containing some photos of the Officine Michelucci, which also lacks an archive [Dezzi Bardeschi 1980].

\subsection{Architectural description}

The Mausoleum is composed of a large and impressive staircase (Fig. 2) that leads the visitor to the decorated entrance gate of the main room ot the first level. This room is characterized by a ribbed cross-vault and a polygonal apse, covered with a ribbed half-dome, where an altar was located (Fig. 3). The tombs were both positioned under the flooring and on the two sides of the chapel, where the signs of the presence of two big coffins are still clearly visible. According to some authors, these coffins were made of white Carrara marble. The interior part of the chapel was painted by Carlo Coppedè. Still visible are some traces of a starry sky and of other decorations on the vault and the half-dome [Formenti and Magnani 1905, Brancaccio 2011].
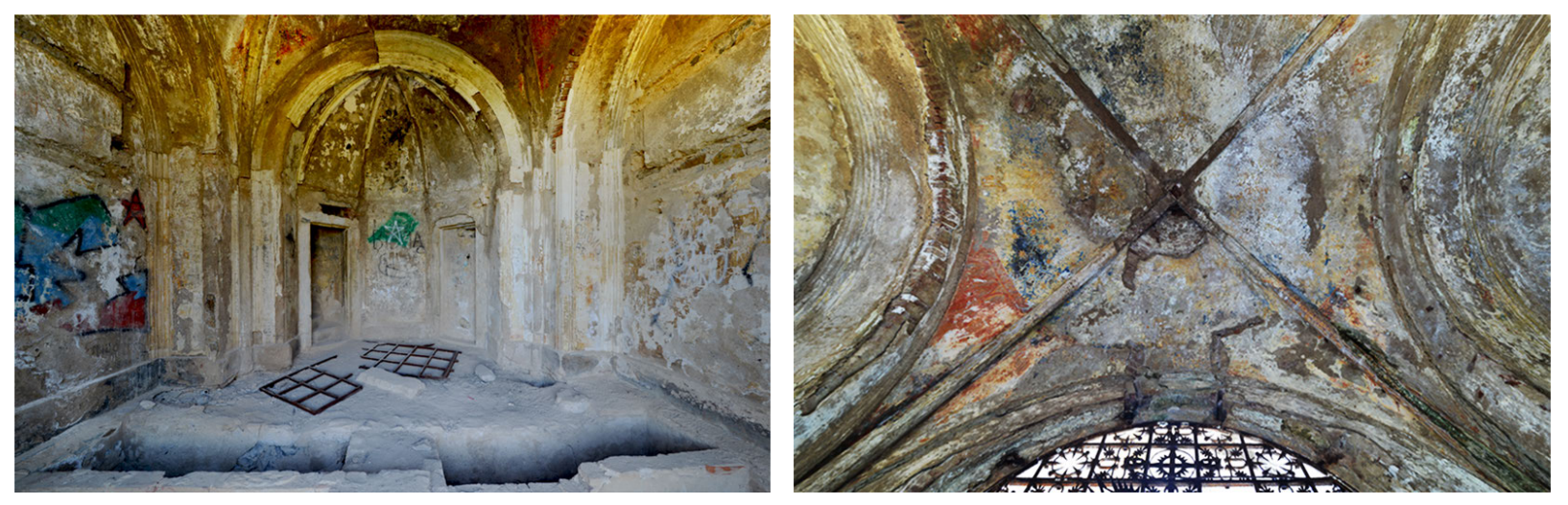

Figure 3. Interior of ground floor and the vault.

The door at the left of the altar leads to a steep and narrow staircase that goes to an upper leve where there is a very small room with an iron helicoidal staircase (Fig. 5) arriving at the lantern.

From this room, going up a couple of steps, it is possible to see a breathtaking view of Elba (Fig. 4). 

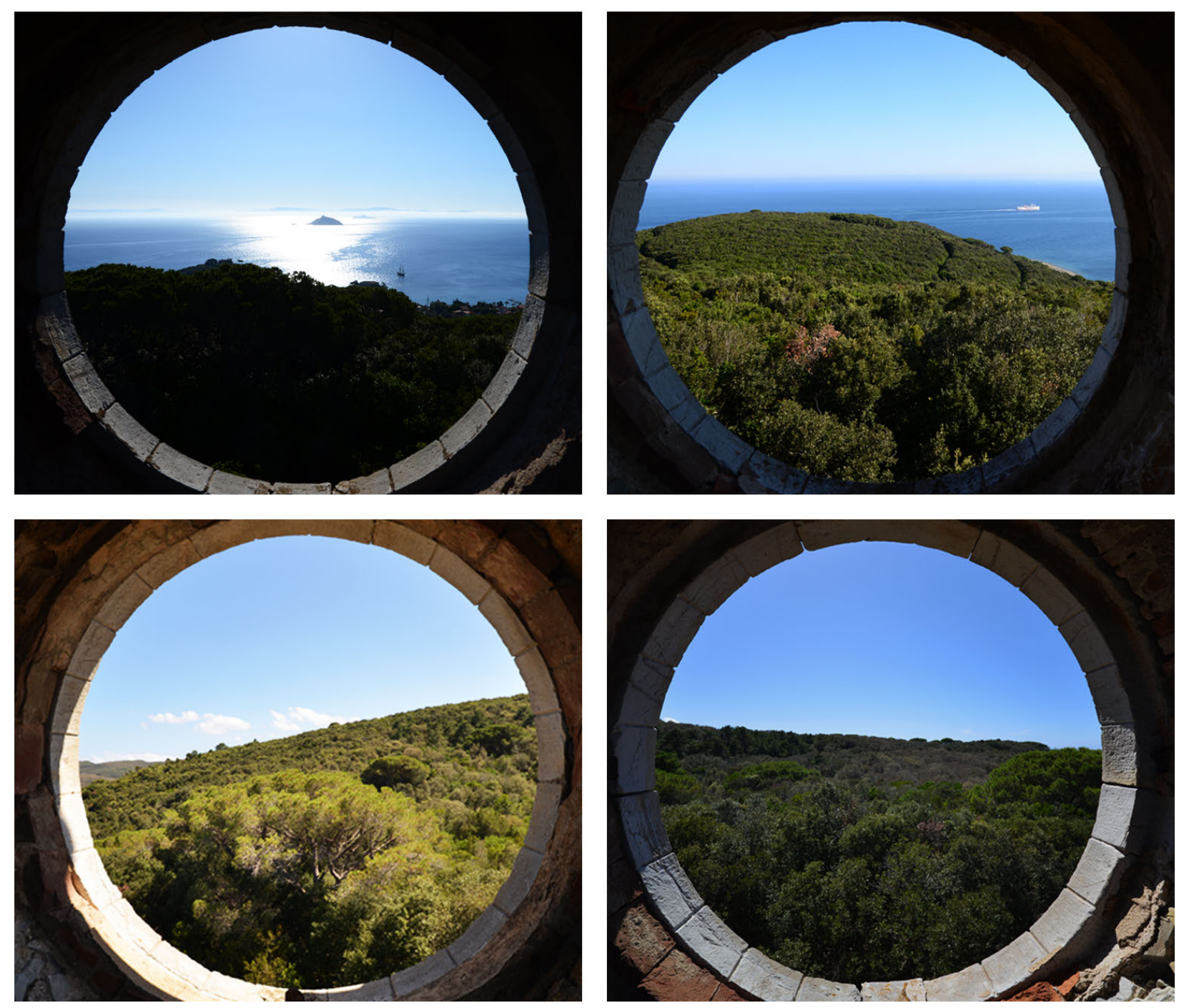

Figure 4. Views on landscape by the oculi at the first floor of Mausoleum.

Unfortunately, at the time of the construction of the chapel, these four oculi were closed with windows, which have now totally disappeared: the salty air entering through these openings has caused the rusting of the staircase, which is now in a state of collapse and impossible to use. 


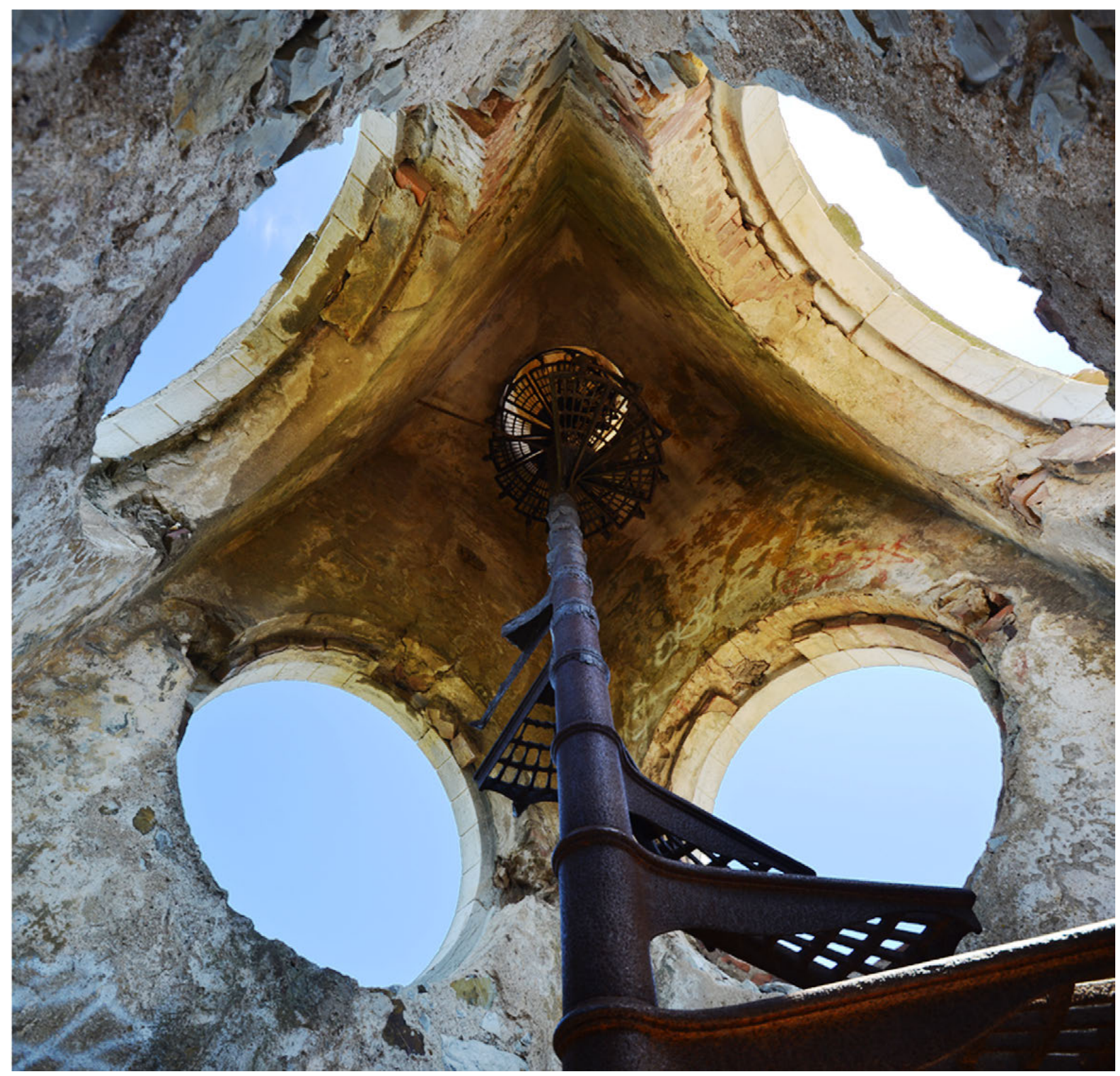

Figure 5. View on interior of first floor - the four oculi and the iron staircase.

\subsection{Reflection on the actual state of preservation}

The Mausoleum is located on the top of a hill called Monte Lentisco, its location is characterized by a flourishing vegetation that in years have grown more and more, surrounding more closely the monument, invading the staircase with the roots and causing the collapse. Some shrubs are also visible on the façades. An historical photograph [A.S.F.] of the mausoleum makes it possible to define the differences between the original and current condition of the interior of the building (Fig. 7). 
What is most evident is the lack of some important parts of the balustrade, of the entrance gate and of some sculptural pieces. It is also evident, after a first visit to the chapel, that many of these items were intentionally removed. We may also observe several phenomena of decay: the presence of lichens and moisture, the collapsed staircase at the entrance, and the degradation of the interior. This is one of the most dangerous conditions of the current state of the chapel: as the access is open to everyone, it is not inconceivable that a visitor might fall down while trying to reach the entrance. Over the study surfaces of the chapel, is possible to see much damage caused by humans. The two heads on the beaks of the side ships are no longer present in the area, so it makes sense to think of a theft. The same is true for some parts of the balustrade. The columns grouped at the side of the door have been engraved, and graffiti are visible on the left one.

\section{THE WORKFLOW ON THE TONIETTI MAUSOLEUM}

The work on the Tonietti Chapel was carried out with an initial bibliographic and archival search that produced the results shown in Fig. 6.

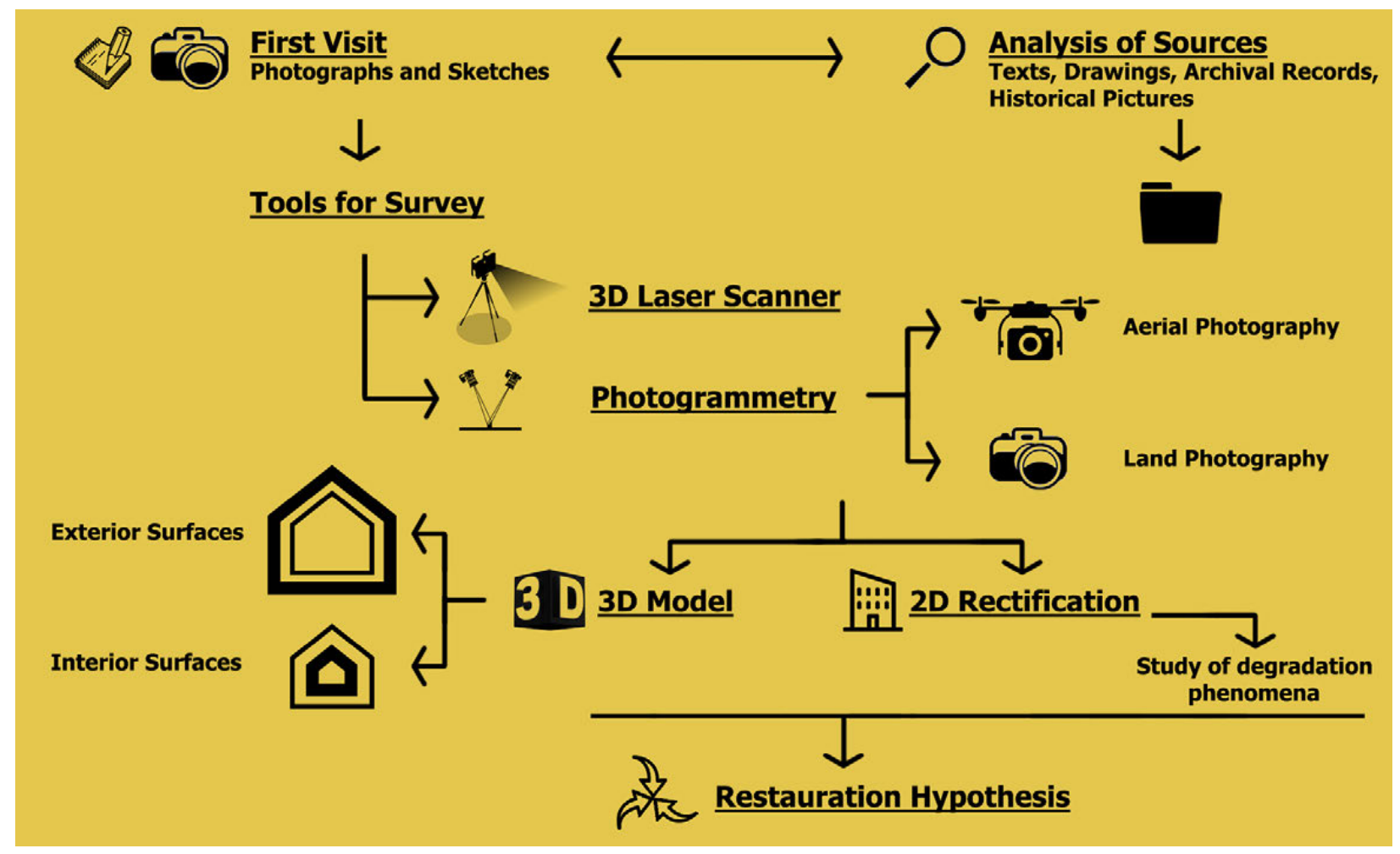

Figure 6. Diagram of workflow.

After this, the work continued with the digital survey and its data elaboration. It is important to highlight that what is covered in this paper is just the initial part of a more exhaustive research 
project that will probably be the subject of future publications. This initial search is of utmost importance for continuing the Mausoleum studies with a precise analysis of the state of degradation and a hypothesis of restoration, conservation and musealization.

\subsection{A preventive site inspection for a survey}

The first inspection of the Tonietti Chapel was done in May 2016. This first approach had the function of understanding exactly what might have been the advantages and disadvantages of a digital survey campaign of the structure. From this first inspection, we noticed the presence of a long gravel road, with many curves and a significant height. The second observation regarded the state of the chapel: it was surrounded by a dense network of medium and tall trees, which on two sides come very close to the structure, not allowing the viewer to take pictures moving away from its exterior perimeter. To solve this problem, at least partially, we removed a portion of the surrounding vegetation, and some branches were bent back, thereby increasing visibility. Finally, some we noted the considerable height of the building and on the inability of reaching the second level, owing to the unsafe conditions of the iron stairs.

\subsection{The digital survey campaign}

The survey campaign using 3D laser scanner has been carried out over two days. Starting from the access door, we covered first the interior and then the exterior, for a total of 65 stations.

The instrument used is a phase-shift LS -Imager 5006h- by Zoller+Fröhlich. This tool works in a range from 0.4 meters to 79 meters, although the best data are obtained in the range between 1 and 50 meters. It scans the points for $360^{\circ}$ on the horizontal and for $310^{\circ}$ on the vertical axis, where it excludes the portion of the points below the scanner tripod. The device can calculate the scans in different modes: starting from the "preview" mode, very quick and with a low number of points, it can work in "middle," "high," "super-high," and "ultra-high," with each jump in quality increasing the time of the scan and the number of resulting points. In our case the scan type was changed according to our requirements: in the interior, where the walls were fairly close to the scanner's station points, we used the "preview" and "medium" mode. The external scans were always made in "high" and once even in "super-high" mode, to reach the lantern.

The issues mentioned above caused a partial final point cloud, and these results were also affected by the presence of different projections highlighted by the truncated-pyramid shape of the chapel.

\subsubsection{Processing}

The processing work was performed by means of specific software to manage the point cloud. The obtained 65 scans, in original .ZFS format, were registered with the automatic procedure on Autodesk Recap 360 Pro. This software automatically registered all the external scans and most of the internal ones, the only cases where manual intervention was necessary was in the case of the narrow and windy stone staircase. Later, the complete point cloud was exported to .PTS format so that we could switch to Bentley Pointools V8i. This was used because it is very convenient to manage and edit the point cloud with a special clip-box, which allows one to obtain snapshots useful for the preparation of traditional two-dimensional products. It allowed us to obtain plans at different levels, sections and 
elevations, with a good level of detail and precision. This software also allows one to view the cloud in false color (hue) or grayscale (grayscale) and to use a plane shader to display different color planes along the axes or a vector. Re-drawing was performed with Autodesk AutoCAD 2016.

\subsubsection{Results}

Finally, from the LS survey campaign two plans were re-drafted (one for the first level and one for the second), four vertical sections (passing through the key brick of the first floor vault) and the four façades, all with a high level of precision, even despite all the issues explained above. These 2D drawings were rendered at a scale of 1:50. The drawings were used for the basis of the subsequent material and degradation studies.
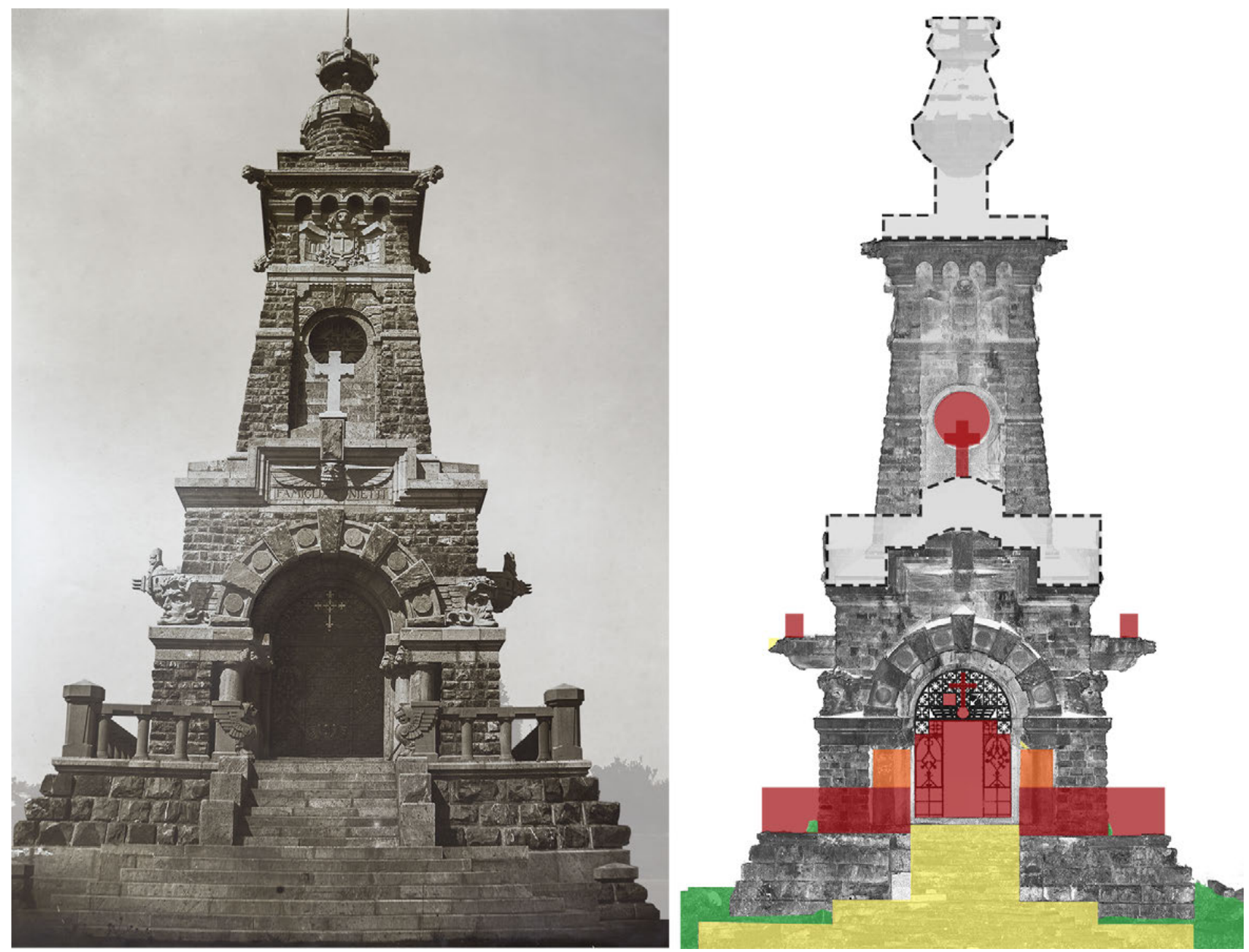

Figure 7. Comparison of first photo and actual state of conservation and diagram of degradation (Image courtesy of Ministero dei Beni e delle attività culturali, drawings by the authors. It is strictly forbidden to reproduce or duplicate the image if not in low resolution and for personal purposes). 


\subsection{The photogrammetric survey campaign}

During the LS survey campaign, a photographic survey with professional equipment was carried out in parallel. This gave us a complete photographic coverage of the building, mapping its environment and the building materials and state of degradation of its facades. Although this work affected the entire structure, here we report a single but relevant application.

\subsubsection{Application on the most important piece of the balustrade: the griffon.}

The Mausoleum was characterized by a balustrade that ran all the way around the first level of the structure and opened at the entrance.

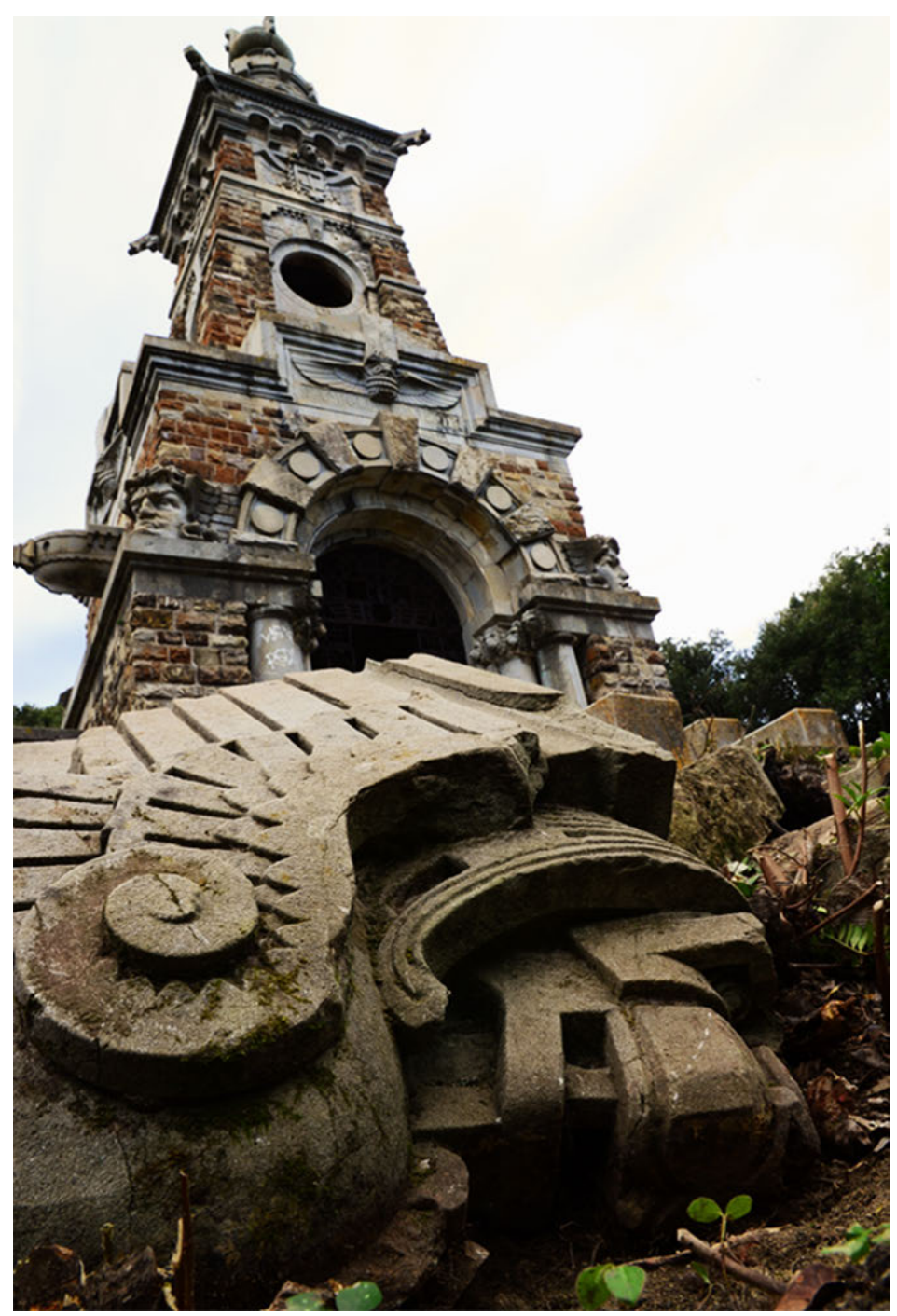

Figure 8. View of the griffon and the Mausoleum. 
As one can note from the historical picture on our left and from the numerous fragment and pieces around the chapel, it was composed of four angular pieces of quadrangular shape, cylindrical lateral pieces and two special pieces at the entrance: two symmetrical winged lions. Today no piece of balustrade is still standing: many of them have been stolen and reused, and some others are scattered around the site. Two lions probably remain in situ thanks to their great weight. One of them is lying on its side (Fig. 8). With a preliminary clearing of the shrubs, it was possible to photograph and reconstruct the geometry via a photogrammetric process and a mirroring of the resultant texturized mesh.
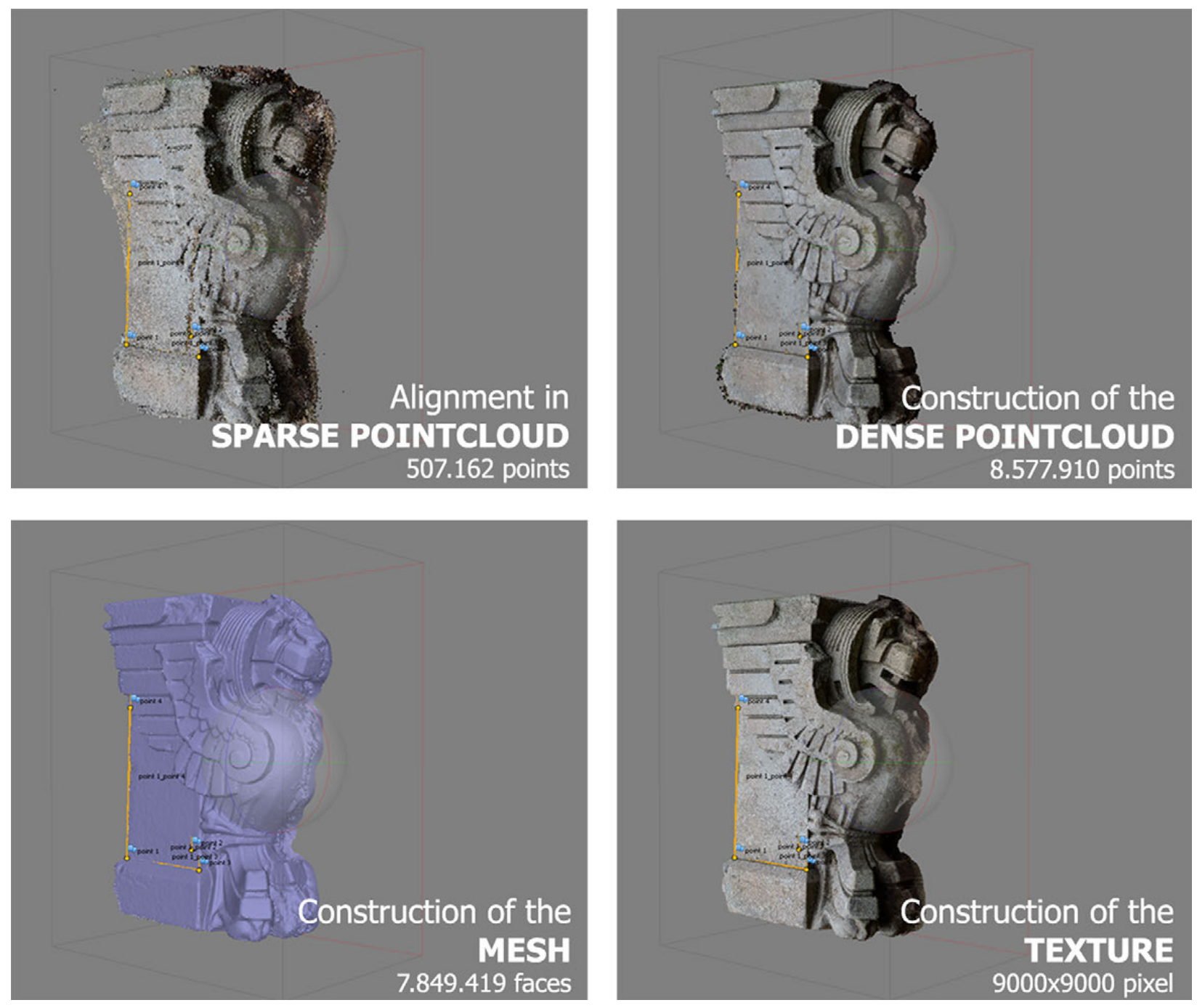

Figure 9. Photogrammetry steps of Griffon.

The photogrammetry was carried out with the software Agisoft Photoscan release 1.2. The final model in .PSX extension has been exported in .OBJ with his own combined material file .MTL (Fig. 9). 
The texturized mesh in .OBJ format has been cleaned, edited and mirrored in Maxon Cinema 4D (Fig. 10).
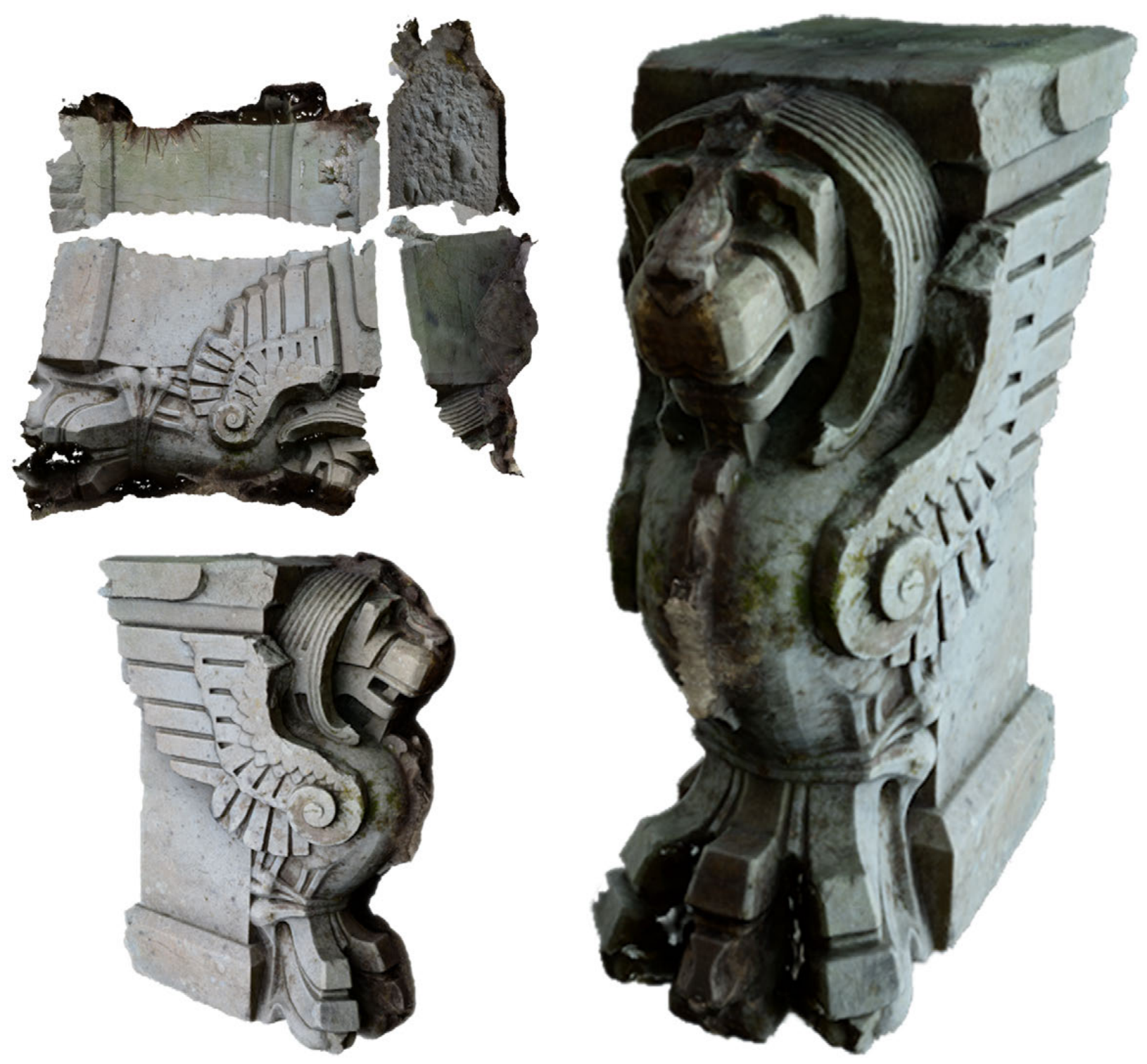

Figure 10. Color MAP and rendering of Griffon model.

The resulting model seems very precise and accurate, preserving both the geometry of the animal and its material definition. Signs of the deterioration of the stone are clearly visible in the original part of the lion: moisture, lichens and missing parts sadly characterized this piece like the entire structure. 


\section{1:732 A. Mancuso et al.}

\section{DISCUSSION}

\subsection{The precarious actual state of preservation of the biggest pieces of Eclectic and Art Nouveau architecture in Italy}

The relatively brief period in which Eclectic Architecture and Art Nouveau Style were dominant in Italy and Europe was soon followed by a rationalist movement that threw the floral style into oblivion [Cresti 1991].

For this reason and because of the strong contradictions and differences between the two movements, the products of the Liberty style were soon abandoned, with the result that one can observe today: the only Liberty buildings still restored and usable are the private ones which have been maintained from one owner to the next with the same economic means.

Contrariwise, when this did not happen, Liberty houses, palaces, monuments or tombs often found themselves abandoned only a few years after their construction, or, if they survived at all, they were in a very precarious condition. Many examples of this adverse fate can be found in monumental cemeteries of the late nineteenth century in the most important cities, which were the centers of the Liberty architectural production (e.g., Milan, Turin, Florence, Viareggio, Montecatini, Livorno, Rome, and Palermo). Sometimes the same thing happened to public buildings: if their use remained constant over the years, their structure and their decorative elements have been maintained until now. However this positive outcome is not encountered in the greater part of the buildings, often abandoned just a few years after their construction owing to a change in architectural taste, of location or due to an improvement of technological needs of people or society. This is the case, for example, of the Terme del Corallo in Livorno, of the Glasshouse of Montecatini-both beautiful buildings now abandoned, whose condition now is only the faded sign of a past and glorious time. Moreover, it must be said that, unlike Liberty, Eclectic architecture suffers not only from a lack of maintenance, but also from a much more serious and dangerous lack of documentation. This problem was encountered in the case study of the Tonietti Chapel in Cavo: for this monument it is still difficult to find the exact date of construction, the original drawings or copies, notices by the architect or by other people who visited the chapel in the first years of twentieth century. This lack of evidence, owing, as said before, to an important loss of interest by people of the period and afterwards, has made research a very difficult matter. As a matter of fact, very little information has been reported over the years, and there has been no confirmation that only a detailed study of the monument can give. For this reason, the present research project is but the first step in a much larger effort to recuperate this important, but sadly neglected, chapter of Italy's modern architectural history.

\section{CONCLUSIONS}

Along with the inspection work, survey, and documentation of the current state of the building, the first stage of this research project on Tonietti chapel included a quick comparison between its current state and its condition when new. This was possible thanks to some photos found in the Archivio di Stato of Florence. This work of comparison also 
helped us to find elements that no longer exist, whose existence would otherwise have been impossible to imagine. This was the case of the heads over the lateral ship bows, which have completely disappeared from the outer perimeter of the building, where a large part of the balustrade is still preserved. Additionally, the comparison between the pictures shot immediately after the end of the construction work and the current state highlights an important issue that the buildings produced in the early 1900s have faced throughout the twentieth century and beyond: the complete lack of interest on the part of the scholarly community and of the territorial governments. Undoubtedly the main factor responsible for this neglect is the ideology of the mechanistic rationalist movement, which helped create indifference, if not outright hostility, to this "old-fashinoned" style of architecture. In particular, in the case of the Mausoleum Tonietti, the neglect was probably intensified by the relationship between the family and the local community.

The aim of this work, still in its initial phase, will be of a comprehensive understanding of this important building by Adolfo Coppedè, continuing the study with an in-depth analysis of its building material and their degradation phenomena and with a final restoration proposal that can give a new life to this fascinating monument, symbol of the eastern area of the Elba Island. This will confer on the Mausoleum Tonietti the importance it deserves: through a possible future restoration project we can expand the monument's current purely ornamental function in the Elban landscape and make it once again an active component of the island's cultural tourist route. Above all, we will situate this building, its architectural movement, and analogous contemporary works in the evolution of Italian architectural history, providing the necessary clarifications and corrections, in order to create a meaningful picture useful for the formation of future architects and architectural historians.

\section{REFERENCES}

Bossaglia Rossana. 1987. Archivi del Liberty italiano: architettura. Milano: Franco Angeli.

Bossaglia Rossana and Cozzi Mauro. 1982. I Coppedè. Genova: Sagep Editrice.

Brancaccio Loredana. 2011. Adolfo Coppedè agli esordi dell'Elba contemporanea. Livorno: Sillabe. Mediaprint.

Cresti Carlo. 1991. Firenze 1896-1915 : la stagione del Liberty. Firenze: Alinea.

Dezzi Bardeschi Marco. 1980. Le Officine Michelucci e l'industria artistica del ferro in Toscana (1834-1918). Pistoia: Cassa di Risparmio di Pistoia e Pescia.

Docci Mario and Fiorucci Tiziana. 2005. Metodologie innovative integrate per il rilevamento dell'architettura e dell'ambiente; Roma: Gangemi Editore.

Fantini Valentina. 2014. Abandoned Art Nouveau in Italy. Document the Built Heritage before its lost, in Proceeding of the 18th International Conference on Cultural Heritage and New Technologies 2013 (CHNT 18, 2013). Vienna: MuseenderStadtWien - Stadtarchäologie.

Formenti Carlo and Magnani Francesco. 1905. Cappella Gentilizia della Famiglia Tonietti all'Isola d'Elba, Architetto Adolfo Coppedè in L'edilizia Moderna, Periodico Mensile di Architettura 


\section{1:734 A. Mancuso et al.}

Pratica e Costruzione, Anno XIV - Fasc.1. Milano: Modiano.

Giusti Maria Adriana. 1996. Le età del Liberty in Toscana. Proceedings of the Conference in Viareggio, 29-30 September 1995. Firenze: Octavo Franco Cantini Editore.

Guidi Gabriele, Russo Michele and Beraldin Jean-Angelo. 2010. Acquisizione 3D e modellazione poligonale, McGraw-Hill Companies,

Milano.

Insabato Elisabetta and Ghelli Cecilia. 2007. Guida agli Archivi di Architetti e Ingegneri del Novecento in Toscana. Firenze: Edifir.

Lambardi Sebastiano. 1966. Memorie antiche e moderne dell'Isola d'Elba. Bologna: Forni Ed.

Ninci Giuseppe. 1988. Storia dell'Isola d'Elba. Sala Bolognese: Forni Ed.

Targioni Tozzetti Giovanni. 1768. Relazioni di alcuni viaggi fatti in diverse parti della Toscana. Firenze.

Vanagolli Gianfranco. 2012. Miniere e ferro dell'Isola d'Elba. Tempo spazio lavoro tecnologia immagini. Livorno: Le opere e i giorni.

Verdiani Giorgio and Fantini Valentina. 2012. The "Terme Del Corallo" in Livorno, Italy, a Contribution to Try Going Beyond the Abandon. INTERNATIONAL JOURNAL OF HERITAGE IN THE DIGITAL ERA, vol. 1-1, pp. 15-19

Verdiani Giorgio, Parretti Lorenzo, Fantini Valentina, De Paola Jacopo and Giraudeau Stéphane, 2013. Ad impossibilia nemo tenetur. Three case studies on built heritage elements at risk. In:

BUILT HERITAGE 2013 Monitoring Conservation and Management, Milano, 18-20/11/2013, vol. 1, pp. 574-581

Zecchini Michelangelo. 1971. L'Elba dei tempi mitici. Pisa: Pacini Mariotti Ed.

A.S.F. Archivio di Stato di Firenze

A.S.C.R.M. Archivio Storico Comunale Rio Marina

Received March 2017; revised July 2017; accepted August 2017. 